\title{
Pengolahan Limbah Cair Tahu Menjadi Biogas Menggunakan Reaktor Biogas Portabel
}

\author{
Kardo Rajagukguk* \\ Program Studi Teknik Mesin, Jurusan Teknologi Produksi dan Industri, \\ Institut Teknologi Sumatera \\ *Penulis korespondensi: kardo.rajagukguk@ms.itera.ac.id
}

Histori artikel: diserahkan 05 Februari 2020, direviu 08 Februari 2020, direvisi 25 Februari 2020

\begin{abstract}
One of the environmental problems caused by tofu industries is the waste produced from the tofu production process. The waste generated by tofu industries can be devided into two types, i.e., solid waste and liquid waste. One effort to reduce the environmental damage due to tofu liquid waste from the processing of tofu is to make the liquid tofu waste into biogas. The attemp to convert liquid waste from tofu factories into biogas needs a biogas reactor. The study aimed to design a biogas reactor with a size of $1 \mathrm{~m}^{3}$ (1000 Liters) by using materials and equipment that are very easily available in the market at an affordable price, to determine the pressure, $\mathrm{pH}$ value and the quality of the flame produced when the biogas were used as fuel gas stove. The method used in this study is an experimental method within 30 days. The results showed that biogas pressure increased with increasing time (days). Maximum pressure was reached on day 21, which is $12.2 \mathrm{kPa}$. The average $\mathrm{pH}$ value is 6.91. The temperature in the biogas reactor tends to be stable, with an average temperature of $31^{\circ} \mathrm{C}$. The color of the flame when the biogas from liquid tofu waste were used as a gas fuel for a large flame gas stove is still a mixture of blue and yellow. The utilization of liquid tofu waste into biogas was expected to reduce environmental pollution and make liquid tofu waste become a high economic value and environmentally friendly
\end{abstract}

Keywords: Biogas Reactor, liquid tofu waste, Design, Renewable Energy

DOI: $10.18196 /$ jqt.010210

Web: http://journal.umy.ac.id/index.php/qt

\section{PENDAHULUAN}

Dalam Industri tahu dalam pengolahannya menghasilkan dua limbah yaitu limbah padat dan cair. Limbah padat berupa ampas tahu terjadi pada proses penyaringan bubur kedelai. Limbah padat ini dijual dan diolah oleh pengerajin menjadi tempe gembus, kerupuk ampas tahu, pakan ternak, dan diolah menjadi tepung ampas tahu yang akan dijadikan bahan dasar pembuatan roti kering. Limbah cair seperti yang ditunjukkan oleh Gambar 1 dihasilkan dari proses pencucian, perebusan, pengepresan dan pencetakan. Rata rata bahan baku untuk pembuatan tahu per hari adalah 100-300 kg, tergantung banyaknya permintaan. Dari produksi $100 \mathrm{~kg}$ kacang kedelai menghasilkan limbah cair sebanyak 800 liter per hari. Limbah tahu cair mengandung kadar Chemical Oxygen Demand (COD), Biochemical Oxygen Demand (BOD), Total Suspended Solids (TSS), Total Dissolved Solids (TDS) dan keasaman $(\mathrm{pH})$ yang tinggi (Anggraini et al., 2015). Komposisi limbah cair tahu sebagian besar terdiri dari air $(99,9 \%)$ dan sisanya terdiri dari partikel-partikel padat terlarut (dissolved solid) dan tidak terlarut (suspended solid) sebesar 0,1\%. Partikelpartikel padat dari zat organik $( \pm 70 \%)$ dan zat anorganik $( \pm 30 \%)$. Zat-zat organik terdiri dari $1 \%$ karbohidrat (terutama stachyose dan sukrosa), 0,1-0,8\% protein, 0,4-1,0\% lemak, dan sekitar 0,4\% mineral (Chua \& Liu, 2019). 
Tabel 1 menunjukkan hasil analisis kimia limbah cair tahu. Baku mutu limbah cair industri produk makanan dari kedelai menurut Kep.Men.LH. No. Kep-51/MENLH/10/1995 tentang Baku Mutu Limbah Cair bagi Kegiatan Industri, kandungan maksimum yang diperbolehkan untuk BOD, COD dan TSS berturut-turut adalah 50, 100 dan $200 \mathrm{mg} / \mathrm{L}$, sehingga jelas bahwa limbah cair industri tahu ini telah melampaui baku mutu yang dipersyaratkan. Limbah cair pabrik tahu memiliki kandungan senyawa organik tinggi yang memiliki potensi untuk menghasilkan biogas melalui proses an-aerobik (Faizal et al., 2016)

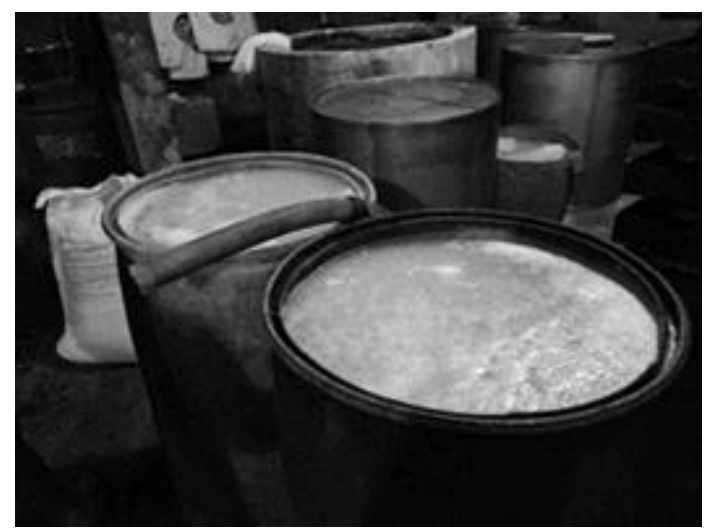

GAMBAR 1. Limbah cair tahu

Komposisi limbah cair tahu sebagian besar terdiri dari air $(99,9 \%)$ dan sisanya terdiri dari partikel-partikel padat terlarut (dissolved solid) dan tidak terlarut (suspended solid) sebesar $0,1 \%$. Partikel-partikel padat dari zat organik $( \pm 70 \%)$ dan zat anorganik $( \pm 30 \%)$. Zat-zat organik terdiri dari $1 \%$ karbohidrat (terutama stachyose dan sukrosa), $0,1-0,8 \%$ protein, $0,4-$ $1,0 \%$ lemak, dan sekitar $0,4 \%$ mineral (Chua \& Liu, 2019).

Tabel 1. Hasil analisis sifat kimia limbah cair tahu (Anggarini et al.,2015)

\begin{tabular}{cccc}
\hline No & Parameter & Satuan & Nilai \\
\hline 1 & COD & $\mathrm{mg} / \mathrm{L}$ & 29.700 \\
2 & BOD & $\mathrm{mg} / \mathrm{L}$ & 8.852 \\
3 & TSS & $\mathrm{mg} / \mathrm{L}$ & 936 \\
4 & $\mathrm{pH}$ & - & 3,6 \\
\hline
\end{tabular}

Limbah cair langsung dibuang ke lingkungan sekitar. Limbah tahu menyebabkan banyak masalah lingkungan. Gambar 2 menunjukkan limbah cair tahu jika langsung dibuang ke badan air akan menurunkan daya dukung lingkungan, sehingga industri tahu memerlukan suatu pengolahan limbah yang bertujuan untuk mengurangi resiko beban pencemaran yang ada. Limbah yang dibuang langsung ke lingkungan sekitar menyebabkan munculnya persoalan lingkungan dan kesehatan masyarakat. Masyarakat disekitar industri pengolahan tahu kerap mengeluhkan pencemaran yang terjadi sebagai akibat dari pembuangan limbah tahu. Pencemaran lingkungan yang terjadi antara lain polusi udara, air hingga kebersihan lingkungan menjadi persoalan yang dihadapi desanya. Limbah cair pabrik tahu ini memiliki kandungan senyawa organik yang tinggi. Tanpa proses penanganan dengan baik, limbah tahu menyebabkan dampak negatif seperti polusi air, sumber penyakit, bau tidak sedap, meningkatkan pertumbuhan nyamuk, dan menurunkan estetika lingkungan sekitar pabrik pembuatan tahu.

Berdasarkan observasi peneliti dilapangan, beberapa pabrik tahu skala rumah tangga yang terletak di kecamatan Kedamaian, Bandar Lampung tidak memiliki proses pengolahan limbah cair. Banyak pemilik pabrik tahu tidak ingin mengolah limbah cairnya disebabkan karena kompleks dan tidak efisiennya proses pengolahan limbah. Beberapa penyebab industri tahu tidak melakukan pengolahan limbah cairnya yaitu: keterbatasan dana untuk membangun dan mengoperasikan IPAL, tidak tersedia teknologi pengolahan limbah untuk industri kecil, pengusaha tidak melihat kemanfaatan pengolahan limbah cair, tingkat kesadaran masyarakat terhadap lingkungan hidupnya masih rendah, dampak pembuangan limbah terhadap lingkungan tidak muncul spontan sehingga masyarakat seakan resisten.

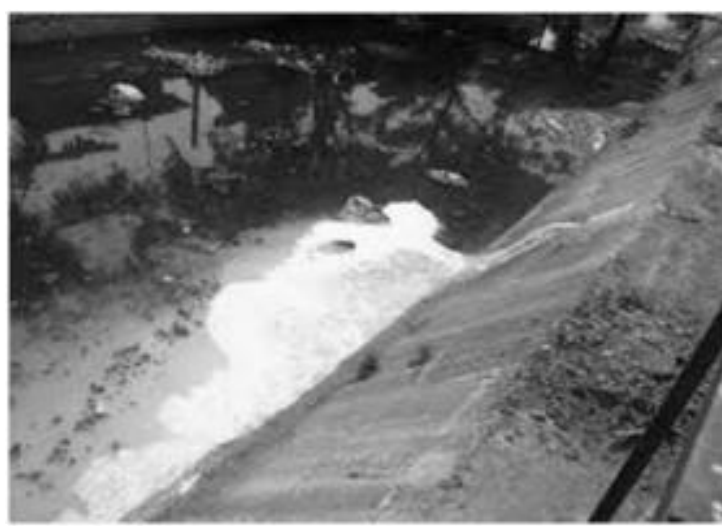

GAMBAR 2. Limbah cair tahu yang dibuang langsung ke lingkungan sekitar 
Permasalahan yang juga terjadi bagi masyarakat pelaku industri tahu yaitu belum mampu memanfaatkan limbah tahu sebagai penghasil energi alternatif (energi terbarukan) pengganti kayu dan Bahan Bakar Minyak (BBM), dimana kegiatan sehari-hari mereka sangat tergantung pada gas dan kayu baik untuk memasak. Hal ini sangat berdampak terhadap pendapatan dari masyarakat pelaku industri tahu tersebut.

Biogas adalah gas yang dihasilkan dari limbah rumah tangga, kotoran hewan, kotoran manusia, sampah organik dan sebagainya yang mengalami proses penguraian atau fermentasi bahan-bahan organik oleh bakteri-bakteri anaerob. Pengolahan limbah secara anaerobik akan menghasilkan biogas yang terdiri dari $\mathrm{CO}_{2}$ dan $\mathrm{CH}_{4}$. Produksi gas juga tergantung pada kinerja bakteri metanogen yang dipengaruhi oleh $\mathrm{pH}$, suhu, kandungan nutrient dan waktu retensi. Energi biogas diperoleh melalui metode digester anaerobic (Moertinah, 2010). Metode ini menggunakan beragam jenis mikroba yang dapat mengubah biomassa dan limbah menjadi biogas dengan cara mendegradasi material organik tanpa melibatkan oksigen dan bantuan bakteri (Dahunsi et al., 2017). Proses anaerobik sangat cocok untuk mengolah limbah cair yang mengandung bahan organik kompleks seperti limbah dari industri makanan, minuman, bahan kimia dan obat-obatan. Bahan organik tersebut didegradasi menjadi senyawa sederhana dan stabil melalui empat tahap yaitu hidrolisis, asidogenesis, asetogenesis dan methanogenesis (Moertinah, 2010).

Kandungan biogas didominasi oleh $\mathrm{CH}_{4}$ (gas metana) yang berpotensi besar sebagai sumber energi untuk memasak, pemanasan atau dikonversi menjadi listrik. Komponen biogas yang dihasilkan dari proses fermentasi berupa gas metana $\left(\mathrm{CH}_{4}\right)$ sekitar $54-70 \%$, gas karbondioksida $\left(\mathrm{CO}_{2}\right)$ sekitar $27-45 \%$, nitrogen $\left(\mathrm{N}_{2}\right) 3 \%-5 \%$, hidrogen $\left(\mathrm{H}_{2}\right)$ sebesar $1 \%, 0,1 \%$ karbonmonoksida (CO), 0,1\% oksigen $\left(\mathrm{O}_{2}\right)$, dan sedikit hidrogen sulfida $\left(\mathrm{H}_{2} \mathrm{~S}\right)$. Gas metana $\left(\mathrm{CH}_{4}\right)$ yang merupakan komponen utama biogas merupakan bahan bakar yang berguna karena mempunyai nilai kalor yang cukup tinggi, yaitu sekitar 4800 sampai $6700 \mathrm{kkal} / \mathrm{m}^{3}$. Karena nilai kalor yang cukup tinggi maka biogas dapat dipergunakan untuk keperluan penerangan, memasak, menggerakan mesin dan lain sebagainya. Biogas merupakan hasil akhir dari proses anaerobik dengan komponen utama $\mathrm{CH}_{4}$ dan $\mathrm{CO}_{2}, \mathrm{H}_{2}, \mathrm{~N}_{2}$, dan gas lain seperti $\mathrm{H}_{2} \mathrm{~S}$.

Setiap satu meter kubik biogas setara dengan setengah kilogram gas alam cair (liquid petroleum gases), atau setengah liter bensin atau setengah liter minyak diesel. Biogas sanggup membangkitkan tenaga listrik sebesar 1,25-1,50 kilo watt hour (kwh). Usaha untuk mengkonversi limbah cair pabrik tahu menjadi biogas, maka perlu suatu reaktor biogas yang dapat menghasilkan gas metana. Pemanfaatan limbah tahu menjadi biogas diharapkan dapat mengurangi pencemaran lingkungan dan membuat air limbah cair tahu menjadi bernilai ekonomi tinggi dan ramah lingkungan.

Perencanaan reaktor biogas merupakan hal yang sangat penting untuk diteliti. Perencanaan reaktor biogas ditentukan oleh beberapa faktor yaitu bahan limbah yang digunakan untuk menghasilkan biogas, konstruksi reaktor biogas, lokasi, kapasitas reaktor, dan biaya (Sreekrishnan et al., 2004). Banyak kendala yang dihadapi dalam pengembangan teknologi biogas. Salah satu kendalanya adalah kekurangan technical expertise. Banyak reaktor biogas yang tidak berfungsi akibat dari kesalahan konstruksi. Desain yang tidak sesuai dengan kebutuhan pemakai dapat menimbulkan berbagai masalah.

Ada beberapa masalah yang timbul yaitu pengoperasian reaktor sulit, sulitnya perawatan dan pemeliharaan secara berkala, bahan dan alat yang digunakan dalam pembuatan reaktor sudah didapat di pasaran, pembuatan reaktor yang rumit, serta biaya pembuatan (konstruksi) reaktor biogas yang mahal. Dalam menentukan tipe reaktor biogas yang akan dikembangkan sebaiknya mempertimbangkan aspek teknis, ekonomis, bahan biogas dan lokasi. Dalam penelitian ini telah dirancang sebuah reaktor biogas. Tujuan penelitian ini adalah mendesain sebuah reaktor biogas yang menggunakan bahan-bahan dan peralatan yang sangat mudah didapatkan di pasaran dengan harga yang terjangkau, mengetahui tekanan, nilai $\mathrm{pH}$ pada reaktor biogas dan kualitas nyala api yang dihasilkan ketika biogas dimanfaatkan sebagai bahan bakar kompor gas. 


\section{METODE PENELITIAN}

Penelitian ini diawali dengan tahap studi pustaka untuk mengetahui jenis reaktor biogas, mempelajari instalasi biogas dan proses terbentuknya biogas, survei lokasi limbah cair tahu, wawancara dengan pemilik industri tahu. Pemilihan jenis biodigester (reaktor) disesuaikan dengan kebutuhan dan kemampuan pembiayaan atau finansial. Secara umum model instalasi peralatan untuk pemafaatan limbah cair tahu menjadi biogas ditunjukkan oleh Gambar 3.

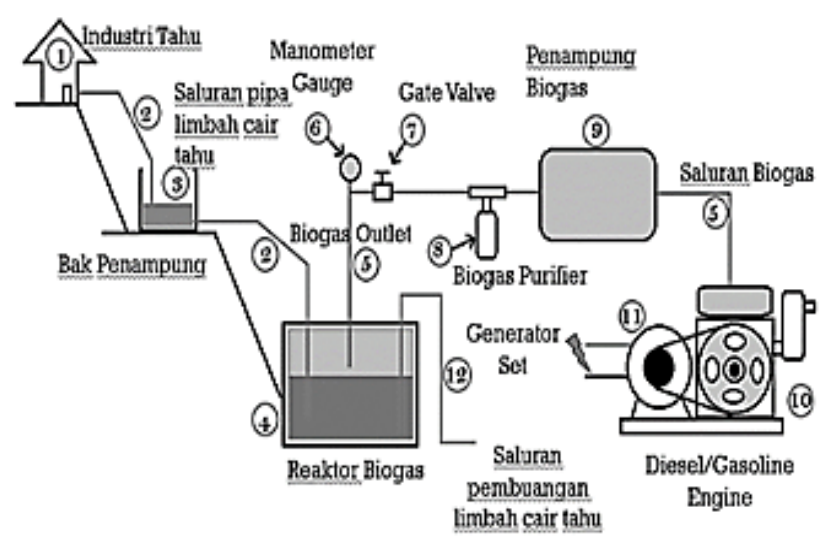

GAMBAR 3. Model instalasi reaktor biogas memanfaatkan limbah cair tahu

Selanjutnya merekayasa instalasi biogas pada saluran masuk dan saluran keluar limbah cair tahu, saluran keluar biogas, instalasi pengukuran tekanan tabung gas, serta penampungan dari biogas. Selanjutnya dilakukan pengujian dan pengukuran kapasitas reaktor biogas dan spesifikasi reaktor. Bahan dalam penelitian ini meliputi tangki Intermediate Bulk Containers (IBC) kapasitas 1000 liter. Bahan tanki IBC ini terbuat dari bahan HDPE (High Density Polyethylene) yang memiliki kelebihan diantaranya kuat, tahan lama, tidak berkarat, anti bocor serta ringan. Bahan lainnya adalah pipa PVC ukuran 2 inch, elbow 2 inch, selang $1 / 2$ inch, schoket drat 2 inch, reducer $2 \times 3 / 4$ inch, low pressure gauge, (manometer biogas), stop kran $1 / 2$ inch, stop kran ball valve 2 inch, nipple $1 / 2$ inch, corong minyak diameter $22 \mathrm{~cm}$, penutup pipa PVC 2 inch, uni seal 2 inch, klem pipa $3 / 4$ inch, seal tape, lem pipa. Peralatan yang digunakan dalam penelitian ini adalah bor listrik, kunci pipa, glue gun, kunci pas, obeng, gergaji besi dan termokopel. Bahan dan alat yang digunakan dalam penelitian ini mudah ditemukan di pasaran dengan harga yang terjangkau.

Reaktor didesain dalam bentuk konstruksi portabel yang terdiri dari tangka utama (tangka digester), saluran masuk dan saluran keluar slurry seperti yang ditunjukkan Gambar 4 . Reaktor fixed dome memiliki volume tetap sehingga produksi gas akan meningkatkan tekanan dalam reaktor. Karena itu, dalam konstruksi ini gas yang terbentuk akan segera dialirkan ke pengumpul gas di luar reaktor.

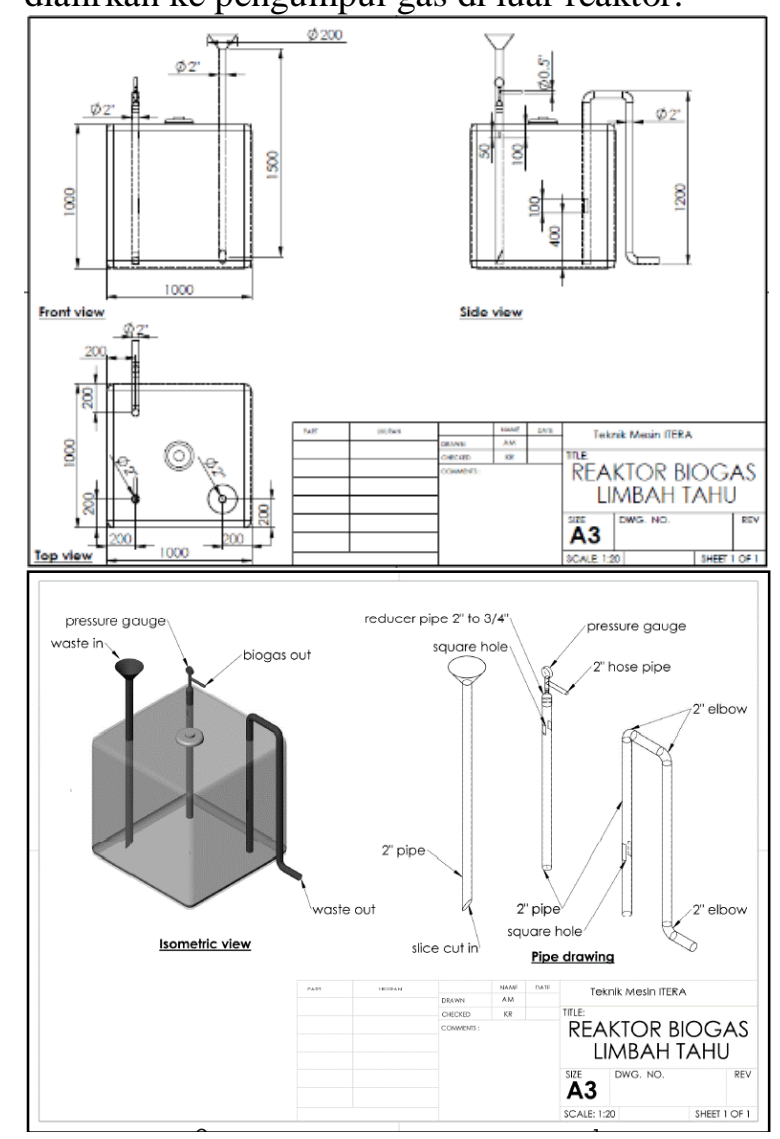

GAMBAR 4. Desain reaktor biogas limbah cair tahu

Adapun tahap penelitian ini meliputi perancangan, perakitan, pengujian hasil rancangan, pengamatan, dan pengolahan data. Desain reaktor biogas dapat kita lihat pada Gambar 4.

Proses pembuatan reaktor biogas dilakukan melalui tahapan sebagai berikut:

1. Menyiapkan material yang dibutuhkan dalam proses pemasangan instalasi.

2. Melakukan pembuatan lobang sebesar 2 inch pada tangki IBC untuk saluran masuk limbah cair tahu dan saluran keluar biogas (gas metana).

3. Memasang shocket drat 2 inch, pipa 2 inch dan uni seal pada saluran masuk, 
saluran keluar gas dan saluran keluar sisa pembuangan akhir.

4. Memasang inlet yaitu berupa corong tempat masuknya bahan limbah cair tahu yang akan di proses dalam reaktor.

5. Memasang reducer pada saluran gas dan disertai pemasangan control valve dan manometer yang sudah dilengkapi dengan nipple $1 / 2$ inch pada saluran keluar gas.

6. Memasang elbow pada saluran keluar limbah tahu hasil fermentasi dan sambungan sampai pada pembuangan akhir.

7. Memasang instalasi lainnya berupa tempat penampungan gas yang dihubungkan dengan selang $3 / 4$ inch lengkap dengan kran.

Reaktor biogas terbuat dari bahan HDPE dengan volume operasional $1.000 \mathrm{~L}$ sesuai dengan yang tersedia di pasaran. Komponen pendukung pada reaktor antara lain saluran masuk limbah cair tahu, saluran keluar (residu), katup pengaman tekanan (control valve) dan saluran gas keluar seperti yang ditunjukkan oleh Gambar 5.

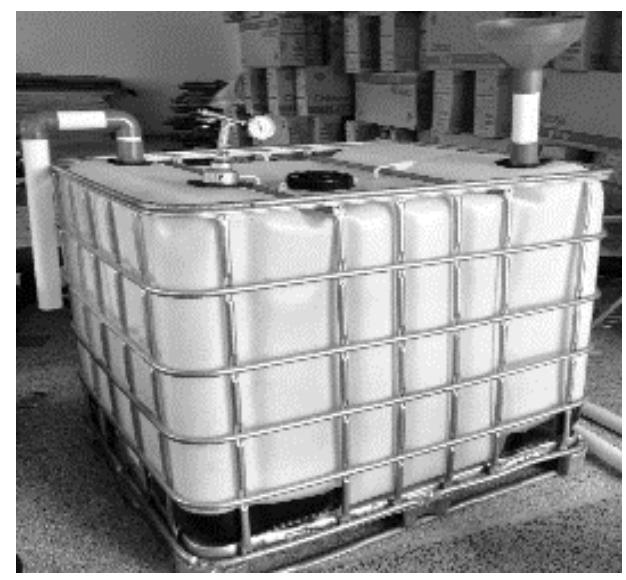

GAMBAR 5. Reaktor biogas limbar cair tahu

\section{HASIL DAN PEMBAHASAN}

Reaktor biogas limbah cair tahu yang sudah dibuat ditunjukkan oleh Gambar 5. Setelah reaktor biogas selesai dirakit, maka tahapan selanjutnya adalah pengujian kebocoran. Terdapat beberapa cara untuk mendeteksi adanya kebocoran pada reaktor biogas, yaitu dengan melakukan pengecekan tekanan, leakage spray, laser gas, dan kamera inframerah. Pendeteksi adanya kebocoran biogas dengan cara pengecekan tekanan diidentifikasikan dengan adanya penurunan tekanan gas secara signifikan. Cara kedua yaitu dengan leakage spray, semprotan ini berbentuk busa, ketika telah teridentifikasi adanya kebocoran biogas, maka busa tersebut akan berubah warna (Clemens et al., 2012). Pengujian dilakukan dengan mengisi udara bertekanan kedalam reaktor dan menutup semua saluran masuk dan saluran keluar. Pengujian kebocoran dilakukan dengan menuangkan cairan busa atau deterjen ke dinding reaktor. Selanjutnya mengamati gelembung udara yang terjadi dan melihat tekanan yang ditunjukkan oleh manometer apakah ada penurunan atau tidak, sehingga nantinya dapat mengindikasikan terjadinya kebocoran.

Pengujian kebocoran dilakukan bertujuan untuk memastikan bahwa bahwa bahan limbah cair tahu yang sudah difermentasikan menghasilkan biogas (gas metana) tidak mengalami kebocoran yang mengakibatkan menurunnya tekanan gas dalam reaktor. Setelah dipastikan tidak ada kebocoran pada reaktor biogas maka pekerjaan selanjutnya adalah melakukan pengujian dengan memasukkan limbah cair tahu sebanyak 1000 L pada saluran masuk. Kemudian tutup saluran masuk dengan penutup pipa 2 inch dan menunggu proses fermentasi limbah cair tahu didalam reaktor biogas hingga menghasilkan gas metana.

Dapat diketahui bahwa luaran berupa reaktor biogas dengan kapasitas $1000 \mathrm{~L}$ telah terlaksana sehingga sudah dapat digunakan untuk mengolah limbah cair tahu menjadi biogas. Dari data hasil observasi dilapangan industri tahu menghasilkan limbah cair tahu rata rata 800 liter per hari. Dengan demikian volume reaktor biogas yang sudah dibuat sudah cukup menampung produksi limbah cair tahu untuk satu hari. Reaktor biogas ini sudah diuji coba dan dapat berfungsi dengan baik dan tidak mengalami kebocoran. Hal ini dapat dilihat dari tidak adanya limbah tahu cair yang keluar dari pipa pembuangan ataupun dari sisi dinding reaktor. Pada hari ketiga manometer penunjuk ukuran tekanan gas sudah mulai menunjukkan kenaikan pada jarum penunjuk, hal ini dapat dikatakan bahwa adanya gas yang terbentuk sebagai awal dari proses pembentukan biogas dari limbah tahu cair. Temperatur yang tinggi umumnya akan memberikan produksi biogas yang baik. 
Bakteri hanya dapat berkembang bila suhu disekitarnya berada pada suhu kamar. Suhu yang baik untuk proses pembentukan biogas berkisar antara $20-40^{\circ} \mathrm{C}$ dan suhu optimum antara $28-30^{\circ} \mathrm{C}$. Dengan temperatur itu, proses pembuatan biogas akan berjalan sesuai dengan waktunya. Tetapi berbeda bila temperatur terlalu rendah (dingin), maka waktu untuk membentuk biogas akan lebih lama (Sreekrishnan et al., 2004).

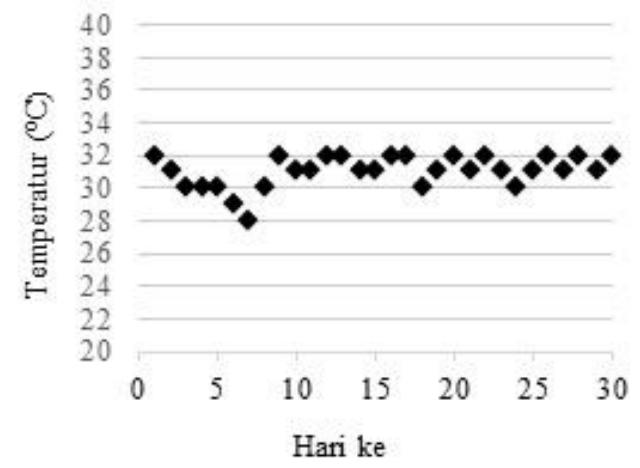

GAMBAR 6. Hasil pengamatan $\mathrm{pH}$ biogas

Gambar 6 menunjukkan hubungan antara waktu tunggu terhadap pengukuran suhu pada reaktor biogas. Dari hasil pengukuran menggunakan termokopel digital diperoleh suhu didalam reaktor biogas cenderung stabil dengan rata-rata suhu $31^{\circ} \mathrm{C}$ dengan suhu maksimal $32^{\circ} \mathrm{C}$ dan suhu minimum $28^{\circ} \mathrm{C}$. Suhu lingkungan diperoleh berkisar $30^{\circ} \mathrm{C}$ dengan suhu maksimal $32^{\circ} \mathrm{C}$ dan suhu minimum $26^{\circ} \mathrm{C}$. Temperatur selama proses berlangsung sangat penting karena hal ini berkaitan dengan kemampuan hidup bakteri pemrosesan biogas, yaitu berkisar $27^{\circ} \mathrm{C}-28^{\circ} \mathrm{C}$ (Sreekrishnan et al. 2004)

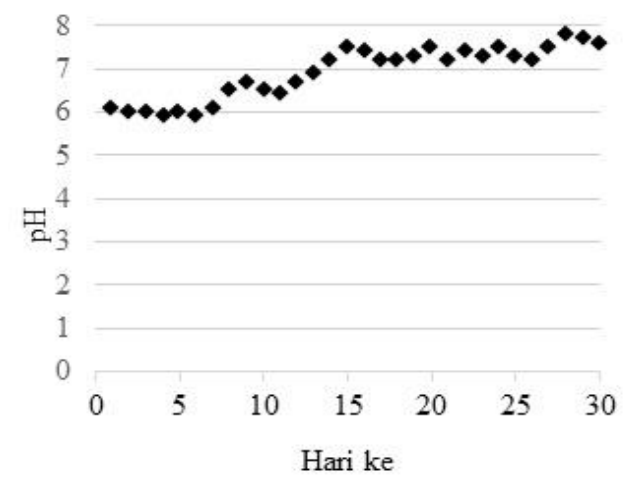

GAMBAR 7. Hasil pengamatan $\mathrm{pH}$ biogas

Nilai $\mathrm{pH}$ merupakan salah faktor penting dalam melakukan uji potensial biogas. Gambar 7 menunjukkan hubungan antara waktu tunggu terhadap pH limbah tahu cair. Selama waktu pengujian, nilai $\mathrm{pH}$ selalu menunjukkan angka yang fluktuatif. Nilai $\mathrm{pH}$ limbah cair meningkat dari hari ke-10 sampai ke-20. Peningkatan tersebut karena senyawa hasil fermentasi maupun asetogenesis sudah dikonversi menjadi $\mathrm{H}_{2}, \mathrm{CO}_{2}, \mathrm{H}_{2} \mathrm{O}$, dan $\mathrm{CH}_{4}$, serta pemecahan protein menjadi $\mathrm{NH}_{4}+$ yang kemudian mudah membentuk senyawa yang bersifat basa. $\mathrm{pH}$ pada sebuah digester biogas juga merupakan fungsi waktu tunggu. Pada periode awal cenderung rendah lalu naik pada periode berikutnya yang menunjukkan bahwa proses asidogenesis dan metanogenesis berlangsung secara terpisah. Nilai $\mathrm{pH}$ optimal untuk produksi metana adalah 7,0 sampai 7,2 akan tetapi pada kisaran 6.8 sampai 8.0 masih diperbolehkan (Budiyono et al., 2013; Jayaraj et al., 2014). Hasil pengukuran Nilai pH dalam penelitian mengunakan digital $\mathrm{pH}$ meter diperoleh rata-rata nilai $\mathrm{pH}$ berkisar 6,91 sehingga nilai $\mathrm{pH}$ dalam reaktor biogas dapat dikatakan cukup baik untuk produksi gas metan. Dalam bioreaktor, terdapat dua bakteri yang berperan, yaitu bakteri asam dan bakteri metan. Kedua jenis bakteri ini harus eksis dalam jumlah yang berimbang. Kegagalan proses pembuatan biogas dapat dikarenakan oleh tidak seimbangnya populasi bakteri metan terhadap bakteri asam yang menyebabkan lingkungan menjadi sangat asam $(\mathrm{pH}$ kurang dari 7) yang selanjutnya menghambat kelangsungan hidup bakteri metan. Keasaman substrat yang dianjurkan berada pada rentang pH 6.5 sampai 8.

Dalam bioreaktor, terdapat dua bakteri yang berperan, yaitu bakteri asam dan bakteri metan. Kedua jenis bakteri ini harus eksis dalam jumlah yang berimbang. Kegagalan proses pembuatan biogas dapat dikarenakan oleh tidak seimbangnya populasi bakteri metan terhadap bakteri asam yang menyebabkan lingkungan menjadi sangat asam $(\mathrm{pH}$ kurang dari 7) yang selanjutnya menghambat kelangsungan hidup bakteri metan. Keasaman substrat yang dianjurkan berada pada rentang pH 6.5 sampai 8 (Budiyono et al., 2013; Jayaraj et al., 2014).

Tekanan biogas selama fermentasi cenderung mengalami perubahan yaitu mengalami kenaikan dan penurunan. Tekanan biogas yang dihasilkan diukur menggunakan digital manometer GM510. Dari grafik dibawah ini 
dapat dilihat perubahan tekanan selama fermentasi.

Gambar 8 menunjukkan hubungan waktu tunggu (retention time) terhadap tekanan biogas yang dihasilkan. Pada hari ke-1 sudah tampak adanya kenaikan tekanan sebesar 0.3 $\mathrm{kPa}$. Pada hari ke-5 hingga ke-18, biogas yang terbentuk meningkat secara signifikan, hal ini dapat dilihat bahwa proses yang terjadi sudah memasuki fase pembentukan biogas yaitu fase asetogenensis dan metanogenesis.

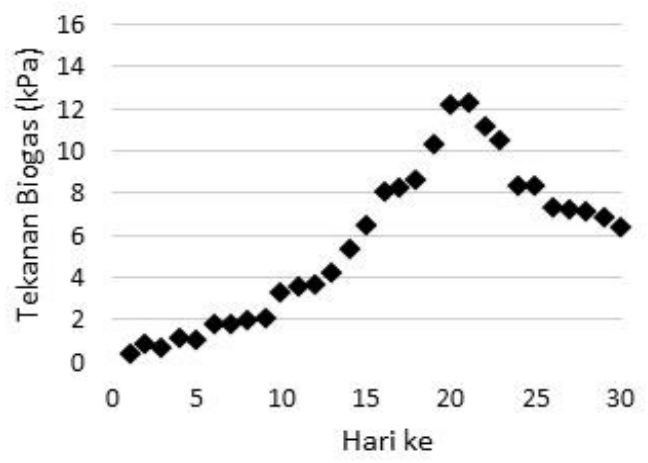

GAMBAR 8. Hasil pengamatan tekanan biogas

Substrat sederhana yang dihasilkan pada tahap asidogenesis digunakan untuk bakteri homoasetogenik pada tahap metanogenesis (Nisrina, 2018). Bakteri tersebut secara konstan mereduksi $\mathrm{H}_{2}$ dan $\mathrm{CO}_{2}$ dan mengubahnya menjadi asam asetik. Produksi biogas yang terbentuk secara fluktuatif, hal ini menunjukkan bahwa bakteri yang ada pada digester memiliki metabolism yang cukup baik.

Semakin bertambahnya hari, tekanan dalam biogas terus bertambah. Tekanan biogas yang semakin meningkat seiring dengan penambahan waktu tunggu (HRT). Tekanan maksimal tercapai pada hari ke 21 yaitu 12.2 $\mathrm{kPa}$. Hal ini sesuai dengan pernyataan Insani, (2013) dan Mahardhian et al. (2017) yang menyatakan bahwa peningkatan penambahan waktu fermentasi dari 10 hari hingga 30 hari meningkatkan produksi biogas sebesar $50 \%$. Hasil ini juga didukung oleh penelitian Jegede et al. (2019) yang menyebutkan bahwa waktu optimum untuk memproduksi biogas dicapai dengan waktu tinggal 30 hari. Hasil penelitian ini menunjukkan terjadi penurunan tekanan pada hari ke 22 sampai hari ke 30 . Hal ini disebabkan karena proses degradasi anaerob dalam biogas sudah semakin berkurang.
Penurunan produksi biogas biogas pada fase ini diakibatkan bakteri sudah kehabisan energi dan tidak mampu lagi untuk melakukan pereduksian senyawa. Tekanan yang dihasilkan oleh biogas ini sudah mampu digunakan untuk menyalakan api dalam kompor gas.

Hasil uji coba penggunaan gas metana sebagai bahan bakar untuk menyalakan kompor gas didapatkan hasil bahwa warna nyala api besar masih campuran warna biru dan kuning, hal ini disebabkan pada awal pembakaran masih banyak kandungan gas selain metana, sedangkan pada nyala api kecil warnanya sudah cenderung biru merata, hal ini karena gas metana sudah sudah homogen. Untuk itu perlu dilakukan penelitian selanjutnya mengenai pemurnian biogas untuk mengurangi gas-gas pengotor yaitu Karbon Dioksida $\left(\mathrm{CO}_{2}\right)$ dan Hidrogen Sulfida $\left(\mathrm{H}_{2} \mathrm{~S}\right)$ sehingga dapat meningkatkan kandungan gas metana sehingga api yang dihasilkan lebih biru dan menghasilkan panas yang lebih baik pada kompor gas. Limbah cair tahu yang sudah terolah ataupun sudah dipakai untuk memproduksi biogas dapat secara aman dibuang ke lingkungan sekitar Sally et al. (2019) dan juga dapat digunakan menjadi pupuk kendang (Nurjannah et al. 2018)

Dengan adanya biogas dari hasil olahan limbah cair tahu maka sangat membantu pengerajin tahu dalam menghemat bahan bakar dimana sebelumnya untuk memproduksi tahu pengerajin dapat mengurangi penggunaan gas LPG atau kayu bakar yang harganya saat ini cukup mahal. Hal ini juga berdampak pada peningkatan perekonomian masyarakat pengrajin tahu.

Naiknya permintaan masyarakat terhadap produksi tahu yang meningkat maka produksi limbah tahu per hari bisa mencapai 2.000 liter (bahan baku kedelai $300 \mathrm{~kg}$ ) sampai 4.000 liter (bahan baku kedelai $500 \mathrm{~kg}$ ). Untuk mengakomodir hal tersebut maka reaktor biogas perlu dibuat sebanyak empat buah yang disambung secara paralel dengan masing masing kapasitas 1.000 liter sehingga dapat menampung limbah cair tahu 4.000 liter per hari. Perlu perlu penelitian selanjutnya untuk mengetahui perbandingan kandungan BOD, COD dan TSS limbah cair tahu dari hasil proses produksi biogas agar aman dibuang ke 
lingkungan sekitar dan mengukur kemampuan degradasi limbah oleh reaktor.

\section{KESIMPULAN}

Reaktor biogas limbah cair tahu kapasitas 1000 liter sudah berhasil dibuat dan diuji coba. Reaktor biogas dibuat menggunakan bahanbahan dan peralatan yang sangat mudah didapatkan di pasaran dengan harga yang terjangkau. Maka dari hasil pengujian reaktor biogas memanfaatkan limbah cair tahu maka dapat disimpulkan bahwa tekanan biogas bertambah seiring bertambahnya waktu (hari). Tekanan maksimal tercapai pada hari ke 21 yaitu $12.2 \mathrm{kPa}$. Rata-rata nilai $\mathrm{pH}$ berkisar 6,91 . Suhu didalam reaktor biogas cenderung stabil dengan suhu rata-rata $31^{\circ} \mathrm{C}$. Warna nyala api ketika biogas dari hasil limbah cair tahu digunakan sebagai bahan bakar kompor gas nyala api besar masih campuran warna biru dan kuning.

\section{UCAPAN TERIMAKASIH}

Ucapan terima kasih disampaikan kepada Institut Teknologi Sumatera yang telah mendanai penelitian ini melalui hibah penelitian ITERA smart tahun 2017.

\section{DAFTAR PUSTAKA}

Anggarini, S., Hidayat, N., Sunyoto, N.M.S. and Wulandari, P.S., 2015. Optimization of hydraulic retention time (HRT) and inoculums addition in wastewater treatment using anaerobic digestion system. Agriculture and Agricultural Science Procedia, 3, pp.95-101.

Budiyono, B., Syaichurrozi, I. and Sumardiono, S., 2013. Biogas production from bioethanol waste: the effect of $\mathrm{pH}$ and urea addition to biogas production rate. Waste Technology, 1(1), pp.1-5

Clemens, J., Kohne, S., Neitzel, S. and Schreier, W., 2012. Leakage control of biogas plants. Orbit, pp.1-8

Chua, J.Y. and Liu, S.Q., 2019. Soy whey: More than just wastewater from tofu and soy protein isolate industry. Trends in Food Science \& Technology, 91, pp.2432
Dahunsi, S.O., Oranusi, S. and Efeovbokhan, V.E., 2017. Cleaner energy for cleaner production: Modeling and optimization of biogas generation from Carica papayas (Pawpaw) fruit peels. Journal of cleaner production, 156, pp.19-29.

Faisal, M., Gani, A., Mulana, F. and Daimon, H., 2016. Treatment and utilization of industrial tofu waste in Indonesia. Asian Journal of Chemistry, 28(3), p.501

Insani, M.D., 2014. Organic Waste Anaerobic degradation with bio-activator-5 Effective Microorganism (EM-5) to Produce Biogas. Jurnal Pendidikan Sains (JPS), 1(3), pp.298-306.

Jayaraj, S., Deepanraj, B. and Sivasubramanian, V., 2014. Study on the effect of $\mathrm{pH}$ on biogas production from food waste by anaerobic digestion. In Proceedings of the 9th Annual Green Energy Conference, Tianjin, China, pp. 25-28.

Jegede, A.O., Zeeman, G. and Bruning, H., 2019. Evaluation of liquid and solid phase mixing in Chinese dome digesters using residence time distribution (RTD) technique. Renewable Energy, 143, pp.501-511

Moertinah, S., 2010. Kajian proses anaerobik sebagai alternatif teknologi pengolahan air limbah industri organik tinggi. Jurnal Riset Teknologi Pencegahan Pencemaran Industri, 1(2), pp.104-114.

Nisrina, H. and Andarani, P., 2018. Pemanfaatan Limbah Tahu Skala Rumah Tangga Menjadi Biogas Sebagai Upaya Teknologi Bersih Di Laboratorium Pusat Teknologi Lingkungan-BPPT. Jurnal Presipitasi: Media Komunikasi dan Pengembangan Teknik Lingkungan, 15(2), pp.139-140

Nurjannah, N., Arfah, N. and Fitriani, N., 2018. Pembuatan Pupuk Organik Cair Dari Limbah Biogas. Journal of Chemical Process Engineering, 3(1), pp. 43-46

Sreekrishnan, T.R., Kohli, S. and Rana, V., 2004. Enhancement of biogas production from solid substrates using different techniques-a review. Bioresource technology, 95(1), pp.1-10.

Putra, G.M.D., Abdullah, S.H., Priyati, A., Setiawati, D.A. and Muttalib, S.A., 2017. Rancang Bangun Reaktor Biogas Tipe Portable dari Limbah Kotoran Ternak Sapi. Jurnal Ilmiah Rekayasa 
Pertanian dan Biosistem, 5(1), pp.369374

Sally, S., Budianto, Y.P., Hakim, M.W.K. and

El Kiyat, W., 2019. Potensi

Pemanfaatan Limbah Cair Tahu Menjadi Biogas Untuk Skala Industri Rumah Tangga di Provinsi Banten. AGROINTEK, 13(1), pp.43-53. 